University of Nebraska - Lincoln

DigitalCommons@University of Nebraska - Lincoln

Faculty Papers and Publications in Animal

Science

Animal Science Department

January 1982

\title{
INDIVIDUAL AND MATERNAL ADDITIVE AND HETEROTIC EFFECTS ON 205-DAY WEIGHT IN BEEF CATTLE
}

\author{
M. D. MacNeil \\ Roman L. Hruska U. S. Meat Animal Research Center, USDA, SEA-AR \\ C. A. Dinkel \\ South Dakota State University, Brookings \\ L. Dale Van Vleck \\ University of Nebraska-Lincoln, dvan-vleck1@unl.edu
}

Follow this and additional works at: https://digitalcommons.unl.edu/animalscifacpub

Part of the Animal Sciences Commons

MacNeil, M. D.; Dinkel, C. A.; and Van Vleck, L. Dale, "INDIVIDUAL AND MATERNAL ADDITIVE AND HETEROTIC EFFECTS ON 205-DAY WEIGHT IN BEEF CATTLE" (1982). Faculty Papers and Publications in Animal Science. 340.

https://digitalcommons.unl.edu/animalscifacpub/340

This Article is brought to you for free and open access by the Animal Science Department at DigitalCommons@University of Nebraska - Lincoln. It has been accepted for inclusion in Faculty Papers and Publications in Animal Science by an authorized administrator of DigitalCommons@University of Nebraska - Lincoln. 


\title{
INDIVIDUAL AND MATERNAL ADDITIVE AND HETEROTIC EFFECTS ON 205-DAY WEIGHT IN BEEF CATTLE ${ }^{1}$
}

\author{
M. D. MacNeil ${ }^{2}$, C. A. Dinkel and L. D. VanVleck ${ }^{3}$ \\ South Dakota State University ${ }^{4}$, Brookings 57007
}

\section{Summary}

Weaning weight records on 47,652 calves in 371 contemporary groups were obtained from the South Dakota Beef Cattle Improvement Association and used to estimate breed individual and maternal additive effects and heterotic effects on 205-d weight. A mixed model was used. Individual additive effects were $-22.6 \pm 1.3 \mathrm{~kg}$ for Red Angus, $-19.0 \pm 1.1$ for Hereford, $-12.2 \pm .9$ for Angus, $-11.5 \pm 3.1$ for Polled Hereford, $-10.1 \pm 2.2$ for Shorthorn, $-7.5 \pm$ 4.9 for Tarentaise, $5.3 \pm 1.6$ for Gelbvieh, $9.5 \pm 1.8$ for Limousin, $11.4 \pm 3.1$ for Chianina, $12.4 \pm 1.2$ for Charolais, $14.6 \pm 1.2$ for Simmental, and $29.7 \pm 3.1$ for Maine Anjou. Maternal additive effects were $-18.9 \pm 2.9 \mathrm{~kg}$ for Polled Hereford, $-9.2 \pm 2.6$ for Shorthorn, $-6.4 \pm$ 1.0 for Hereford, $.3 \pm .9$ for Angus, $6.3 \pm$ 1.3 for Charolais, $11.0 \pm 2.0$ for Red Angus, and $16.9 \pm 2.0$ for Simmental. Pooled estimates of individual and maternal heterosis were 4.4 \pm .4 and $6.8 \pm .4 \mathrm{~kg}$, respectively.

(Key Words: Individual And Maternal Additive Effects, Heterosis, Weaning Weight, Beef Cattle.)

\section{Introduction}

Weaning weight is the salable product of cow-calf operators. Within certain constraints imposed by financial and managerial considera-

\footnotetext{
'Published with the approval of the Director of the South Dakota Agr. Exp. Sta. as Pub. No. 1779 of the Journal Series. Cooperative with and a contribution from Regional Project NC-1. Appreciation is expressed to the South Dakota Beef Cattle Improvement Assoc.; to F. W. Crandall, association secretary and Dr. L. M. Anderson, former association secretary for providing the data, and to Peggy Green for secretarial assistance.

${ }^{2}$ Present address: Roman L. Hruska U. S. Meat Animal Research Center, USDA, SEA-AR, P. 0. Box 166, Clay Center, NE 68933.

${ }^{3}$ Anim. Sci. Dept., Cornell Univ., Ithaca, NY 14853.

${ }^{4}$ Dept. of Anim. Sci., P.O. Box 2170.
}

tions, many producers would seek to maximize weaning weight. Currently, genetic methods to increase weaning weight involve the choice of replacement animals. The low to moderate heritability of weaning weight (Preston and Willis, 1974; Woldehawariat et al., 1977), low reproductive rate of cattle, long generation interval and the relatively low selection differentials make traditional intrabreed phenotypic selection for higher weaning weights a slow and tedious method of improvement (Chapman et al., 1969; Koch et al., 1974; Nwakalor et al. 1976). A more viable option may be to choose among breeds in a way that permits utilization of breed differences in individual and maternal additive effects and heterosis to increase weaning weight.

The primary objective of this study was to estimate, from breed combinations produced by members of South Dakota Beef Cattle Improvement Association, individual and maternal additive effects and heterotic effects on 205-d weight. The secondary objective was to obtain estimates of the within and between contemporary group variance components for 205-d weight.

\section{Materials and Methods}

Description of Data. The 47,652 calf weaning weight records used in this study were furnished by the South Dakota Beef Cattle Improvement Association. Calves born between July 1 and December 31 of each year were excluded and weaning age was confined to the range of 160 to $250 \mathrm{~d}$. Only records on calves with uniquely identified sire and dam breed groups were used. Contemporary groups consisted of calves weaned on the same ranch in any $1 \mathrm{yr}$ and subjected to similar creep feeding management procedures. Calf crops weaned from 371 contemporary groups between 1970 and 1978 were used. Crossbred calves were present in all contemporary groups. Each contemporary group contained at least two calf breed groups. All sire and dam 951

breed groups were represented in three or more 


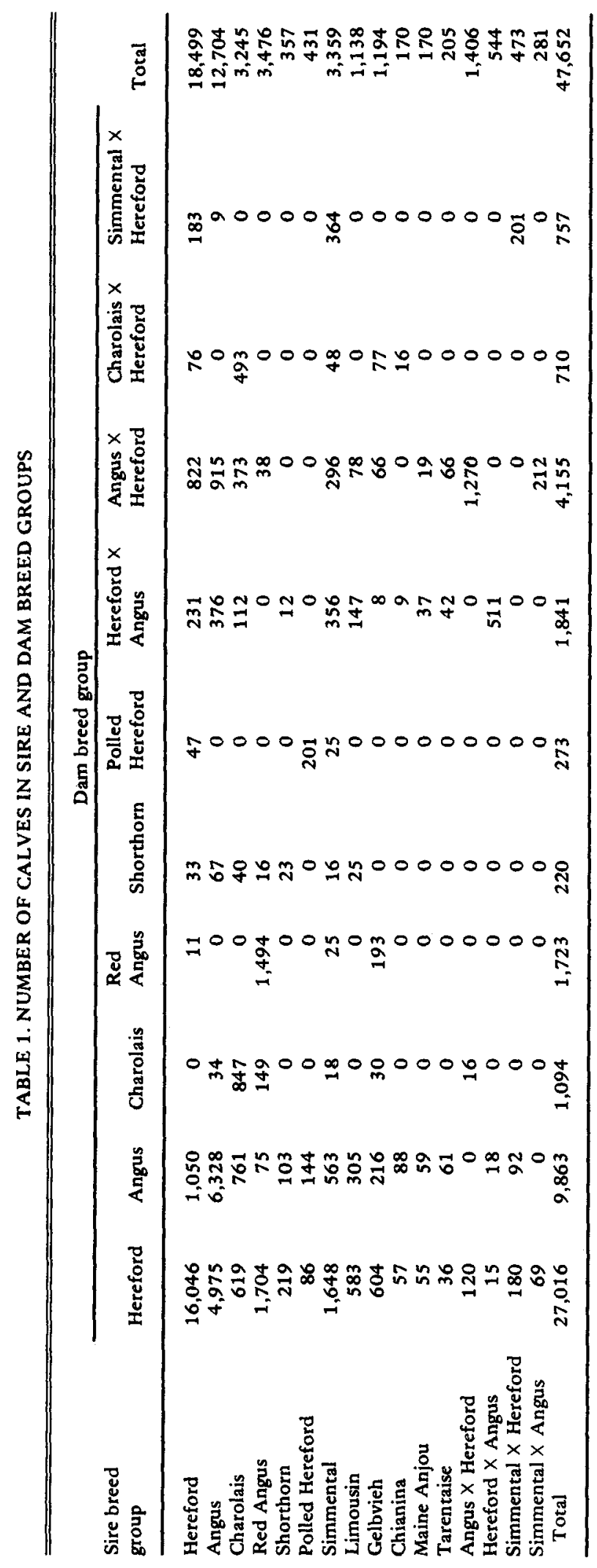


contemporary groups. The degree of crossclassification of sire and dam breed groups is presented in table 1.

Actual calf weaning weights were adjusted to an age-constant basis by the Beef Improvement Federation (BIF, 1976) recommended procedure. Because birth weights frequently were not recorded, a constant birth weight of $31.8 \mathrm{~kg}$ was assumed for all calves. With calves younger than $205 \mathrm{~d}$ at weaning, the use of a constant birth weight tends to increase the 205 $\mathrm{d}$ weight of calves having lower actual birth weights over those of calves having grearer birth weights. Records on calves older than 205 $\mathrm{d}$ at weaning display the opposite bias after adjustment.

Statistical Metbodology. Estimates for individual, maternal additive and heterotic effects (Dickerson, 1969) were obtained from the solution to mixed model equations (Henderson, 1973). The model was:

$$
y=X \beta+Z u+e
$$

where

$y$ is a vector of age adjusted calf weaning weights,

$X$ is a known matrix relating elements of $y$ to the unknown fixed effects to be estimated,

$\beta$ is a vector of unknown fixed effects. Included were a common mean, age of dam effects $(2,3,4$ and $5+y r)$, sex of calf effects (bull, steer and heifer), individual breed additive effects, maternal breed additive effects and pooled individual and maternal heterosis effects,

$Z$ is a known design matrix relating an element of $y$ to an unknown random effect,

$u$ is a vector of unknown random contemporary group effects, assumed to have null mean and variance-covariance structure $1 \sigma_{\mathrm{c}}{ }^{2}$, and

$e$ is a vector of unknown random residual effects, assumed to have null mean and variance-covariance structure $I \sigma_{e}{ }^{2}$. The covariance of $e$ and $u$ was assumed null.

As formulated, the mixed model equations are not independent and no unique solution exists. Therefore, constraints were imposed on the equations such that estimates of age of dam, sex of calf and individual and maternal additive effects each summed to zero. The true underlying biological model would undoubtedly also contain random effects for sire and dam of calf. However, in these data sires and dams were frequently not uniquely and consistently identified. As the analytical model may not truly reflect the underlying biological model, tests of significance should be considered approximate. Duncan's multiple range test, as modified by Kramer (1957), was used for individual and maternal breed additive effect comparisons.

Robison et al. (1981) have presented in greater detail similar methodology for the estimation of genetic parameters from crossbreeding data for the fixed model. For the present study, grand maternal additive effects and individual recombination effects were assumed to be null. Differences among various breed combinations in individual and maternal heterosis were neither estimated nor tested.

To obtain the approximate mixed model equations, an estimate of the ratio of residual variance to contemporary group variance was required. Method I procedures (Henderson, 1953) were used to obtain initial estimates of the necessary variance components. Random effects of contemporary group, calf breed group, age of dam and sex of calf were included in the model as main effects. Interactions of the main effects were assumed unimportant. For these data, the ratio $\left(\sigma_{\mathrm{e}}{ }^{2} / \sigma_{\mathrm{c}}{ }^{2}\right)$ was approximately 1.4. Method I estimators of variance components are biased when fixed effects are assumed random (Henderson, 1953) a condition present with these data. However, estimates of the elements of $\beta$ may be relatively insensitive to small errors in the ratio $\sigma_{\mathrm{e}}{ }^{2} / \sigma_{\mathrm{c}}{ }^{2}$ (Henderson, 1977).

The contemporary group and residual variance component estimators were obtained in the mixed model analysis after iteration by the method of Searle (1971) for mixed models with one random factor. Iteration ceased when the change in $\sigma_{\mathrm{e}}{ }^{2} / \sigma_{\mathrm{c}}{ }^{2}$ between successive rounds was less than 1 .

\section{Results and Discussion}

Best linear unbiased estimates for breed individual and maternal effects on 205-d weight are presented in table 2 . These estimates are the generalized least-square estimates if the ratio $\sigma_{e}{ }^{2} / \sigma_{c}{ }^{2}$ is assumed known. Methodology used to arrive at these estimates differs from that used in most previous studies. The usual procedure has been to estimate parameters of interest through specific linear contrasts. However, specific linear contrasts may not utilize 
TABLE 2. INDIVIDUAL AND MATERNAL EFFECTS ON 205-DAY WEIGHT (KG)

\begin{tabular}{lrr}
\hline Breed direct effect & \multicolumn{1}{c}{ Individual } & \multicolumn{1}{c}{ Maternal } \\
\hline Red Angus & $-22.6 \pm 1.3$ & $11.0 \pm 2.0$ \\
Hereford & $-19.0 \pm 1.1$ & $-6.4 \pm 1.0$ \\
Angus & $-12.2 \pm .9$ & $.3 \pm .9$ \\
Polled Hereford & $-11.5 \pm 3.1$ & $-18.9 \pm 2.9$ \\
Shorthorn & $-10.1 \pm 2.2$ & $-9.2 \pm 2.6$ \\
Tarentaise & $-7.5 \pm 4.9$ & \\
Gelbvieh & $5.3 \pm 1.6$ & \\
Limousin & $9.5 \pm 1.8$ & \\
Chianina & $11.4 \pm 3.1$ & \\
Charolais & $12.4 \pm 1.2$ & $6.3 \pm 1.3$ \\
Simmental & $14.6 \pm 1.2$ & $16.9 \pm 2.0$ \\
Maine Anjou & $29.7 \pm 3.1$ & \\
Avg heterotic effect & $4.4 \pm .4$ & $6.8 \pm .4$ \\
\hline
\end{tabular}

all the information available, particularly that from survey type data bases. The procedures employed in this study made use of all the data and were particularly useful for data not obtained from planned crossbreeding experiments.

The individual additive effect of the Maine Anjou breed was greater $(P<.01)$ than that of any other breed. In contrast, Notter et al. (1978) reported that Maine Anjou sired calves out of 3-yr-old Hereford and Angus cows were significantly lighter than Chianina-sired calves and were similar in weight to Gelvbieh-, Hereford- and Angus-sired calves. Gregory et al. (1978b) found that weaning weights of Maine Anjou-sired calves were similar to those of Gelbvieh- and Chianina-sired calves. Simmental, Charolais and Chianina individual additive effects for 205-d weight were similar and were smaller than that of Maine Anjou. The individual direct effect of the Limousin was less $(\mathrm{P}<.01)$ than that of the Simmental, but similar to those of the Charolais and the Chianina. Smith et al. (1976) found that Limousinsired calves weighed significantly less at $200 \mathrm{~d}$ than Charolais- and Simmental-sired calves, which were similar. The individual additive effect of the Gelbvieh was significantly less than those of the previously mentioned breeds and was greater $(P<.01)$ than those of the Tarentaise, Shorthorn, Polled Hereford and Angus breeds, which were similar. Gelbviehsired calves have been reported as having 200- $d$ weights similar to those of Chianina and Maine Anjou sired calves and significantly greater than those of Hereford- and Angus-sired calves
(Gregory et al., 1978a; Notter et al. 1978). Gregory et al. (1979) found Tarentaise-sired calves to be heavier at $200 \mathrm{~d}$ than Herefordand Angus-sired contemporaries. In the present study, the Hereford individual additive effect was greater $(\mathrm{P}<.01)$ than that of Red Angus, and both the Hereford and Red Angus additive effects were less $(P<.01)$ than those of the Tarentaise, Polled Hereford and Angus breeds.

Among the calves studied, the maternal additive effect of the Simmental breed was greater $(P<.01)$ than that of any other breed appearing on the maternal side of the pedigree. Notter et al. (1978) found that Simmental-sired cows produced calves with greater 200-d weights than Charolais-, Hereford-, and Angussired cows; the maternal additive effects on 200-d weight as deviations from the Hereford and Angus mean were 29.4 and $3.7 \mathrm{~kg}$ for Simmental and Charolais, respectively. Comparable estimates from this study were 20.0 and $9.4 \mathrm{~kg}$ for the respective breeds. The Red Angus maternal additive direct effect was less than that of the Simmental and greater $(P<.01)$ than that of the Charolais. The maternal additive effect of the Angus breed was less $(P<.01)$ than that of the Charolais and greater $(P<.01)$ than that of Shorthorn and Hereford, which were similar. The Polled Hereford maternal additive effect was less $(P<.01)$ than that of the Shorthorn and Hereford. Numerous reports have documented the maternal superiority of the Angus over the Hereford breed of dam (Gregory et al., 1965, 1978a, 1979; Smith et al., 1976). Notter et al. (1978) observed no significant differences in weaning weights of calves out of Hereford-Charolais and Angus-Charolais cross cows. Knapp et al. (1980) suggested that Charolais maternal additive effects are greater than Angus maternal additive effects for 205-d weight. Marshall et al. (1976) found no significant differences in weaning weight between calves from Angus, Charolais and reciprocal cross cows.

Crossbred calves with maximum individual heterosis were $4.4 \pm .4 \mathrm{~kg}$ heavier at $205 \mathrm{~d}$ than straightbred calves. This estimate agrees with the $4.3 \mathrm{~kg}$ advantage in weaning weight reported by Peacock et al. (1978) for $F_{1}$ Angus and Charolais calves over their straightbred contemporaries. Somewhat smaller estimates of individual heterosis for weaning weight were reported by Damon et al. (1959). However, most of the estimates of individual heterosis reported for British breed crosses have been 
greater than that observed in this study (Gregory et al., 1965, 1978a; Rollins et al., 1969; Long and Gregory, 1974; Smith et al., 1976; Gray et al., 1978).

Calves with crossbred dams were $6.8 \pm .4 \mathrm{~kg}$ heavier than their counterparts with straightbred dams. This estimate is within the range of previously published estimates for Bos taurus breeds. Cundiff et al. (1974) reported that weaning weights of calves with Hereford, Angus and Shorthorn $F_{1}$ dams exceeded those of calves with straightbred dams of these breeds by 8.4 kg. As $F_{2}$ calves contribute to estimated maternal heterosis under the assumption made for this study, any negative individual recombination effects could bias downward the estimated maternal heterosis. However, the $7.2 \mathrm{~kg}$ average maternal heterosis reported by Gaines et al. (1966) is in close agreement with the estimate obtained in this study. Ellis et al. (1979) reported a maternal heterotic effect of $4.5 \mathrm{~kg}$ for Hereford, Angus and Charolais cross dams. Knapp et al., (1980) found no significant maternal heterosis for weaning weight in crosses of the Hereford, Angus and Charolais breeds.

The genetic components estimated in this study should be useful for the prediction of 205- $d$ weight when production strategies are planned. Choosing among breeds for maximum weaning weight production depends on the mating system to be used. Given the genetic model used in the present study, heterotic effects would be involved only in the choice among mating systems. Within a mating system, breeds can be chosen by simultaneous consideration of individual and maternal additive effects. However, for the selection of the particular breed combination that will yield maximum weaning weight for each calf weaned, simultaneous consideration of individual and maternal additive effects and heterotic effects is essential. Dickerson (1969) has presented the appropriate genetic expectations of individuals from various mating systems currently used in beef production. Results of this study indicate sufficient divergence among breed resources for application. Those breeds with high estimated individual additive effect components would be most suitable as sire breeds in production systems designed to maximize 205-d weight. Breeds with high estimated maternal additive effect components would be most useful as female parents in crossing.

Interpretation of results from studies con- ducted with field data may be hampered by certain deficiencies inherent in the data. Henderson (1973) has indicated potential biases in the prediction of random effects. Some additional problems may be associated with estimation of or comparisons among fixed effects. First, some producers may not distinguish between levels of fixed effects. For example, some individuals might identify all Herefords, horned and polled, simply as being of the Hereford breed. A second problem can arise if differential selection affecting the dependent variable within levels of a fixed effect results in biased comparisons among the levels. For example, the Simmental by virtue of its high level of productivity may be subject to less intense selection for weaning weight than the Hereford, especially when both breeds are found in the same contemporary groups. In an examination of Record of Performance data from 1971 to 1978, Schaeffer et al. (1981) observed genetic trends in weaning weight that were positive for the Angus, Hereford and Shorthorn breeds, and negative for the Charolais, Limousin, Maine Anjou and Simmental breeds. A second example of selection bias is observed when heavier calves are left intact and lower weighing counterparts are castrated. The difference in weight between bull and steer calves then overstates the true sex effect. By including sex in the statistical model as a fixed effect, each sex class is given equal weight in estimates of other fixed effects. The magnitude of these sources of error and any resulting bias in the results for studies conducted with field data are difficult to quantify. Typically, it is necessary to assume that these sources of bias are either not present or randomly associated with the effects of interest.

After one round of iteration, the estimated between contemporary group variance component $\left(\sigma_{\mathrm{c}}{ }^{2}\right)$ was $255.3 \mathrm{~kg}^{2}$, and the estimated residual variance component $\left(\sigma_{e}{ }^{2}\right)$ was 385.9 $\mathrm{kg}^{2}$. The ratio, 1.51 , is in close agreement with the preliminary estimate used for these analyses. Therefore, additional cycles of iteration were deemed unwarranted. Wilson et al. (1972) reported that 36 and $62 \%$ of the total weaning weight variance among Angus cattle was due to between-herds-within-year and residual components, respectively, in general agreement with the results of this study. Wilson et al. (1972) also found that, among Herefords, 60 and $37 \%$ of the variance, respectively, was attributable to these two sources. 


\section{Literature Cited}

BIF. 1976. Guidelines for uniform beef improvement programs. Beef Improvement Federation recommendation. Beef Improvement Federation, USDA Extension Service, Program Aid 1020.

Chapman, H. D., T. M. Clyburn and W. C. McCormick. 1969. Selection of beef cattle for single traits. J. Anim. Sci. 29:225.

Cundiff, L. V., K. E. Gregory, F. J. Schwulst and R. M. Koch. 1974. Effects of heterosis on maternal performance and milk production in Hereford, Angus and Shorthorn cartle. J. Anim. Sci. $38: 728$.

Damon, R. A., Jr., S. E. McCraine, R. W. Crown and C. B. Singletary. 1959. Performance of crossbred beef cattle in the Gulf Coast region. J. Anim. Sci. 18:437.

Dickerson, G. E. 1969. Experimental approaches in utilizing breed resources. Anim. Breed. Abstr. $37: 191$.

Ellis, W. W., M. R. Ellersieck, L. Langford, Bob Sibbit and J. F. Lasley. 1979. Effects of mating systems on weaning traits in beef cattle. J. Anim. Sci. 48:7.

Gaines, J. A., W. H. McClure, D. W. Vogt, R. C. Carter and C. M. Kincaid. 1966. Heterosis from crosses among British breeds of beef cattle: fertility and calf performance to weaning. J. Anim. Sci. $25: 5$.

Gray, E. F., F. A. Thrift and C. W. Absher. 1978. Heterosis expression for preweaning traits under commercial beef cattle conditions. J. Anim. Sci. 47:370.

Gregory, K. E., L. V. Cundiff, R. M. Koch, D. B. Laster and G. M. Smith. 1978a. Heterosis and breed maternal and transmitted effects in beef cattle. I. Preweaning traits. J. Anim. Sci. 47:1031.

Gregory, K. E., L. V. Cundiff, G. M. Smith, D. B. Laster and H. A. Fitzhugh. 1978b. Characterization of biological types of cattle-cycle II: I. Birth and weaning traits. J. Anim. Sci. 47:1022.

Gregory, K. E., G. M. Smith, L. V. Cundiff, R. M. Koch and D. B. Laster. 1979. Characterization of biological types of cattle-cycle III: 1. Birth and weaning traits. J. Anim. Sci. 48:271.

Gregory, K. E., L. A. Swiger, R. M. Koch, L. J. Sumption, W. W. Rowden and J. E. Ingalls. 1965. Heterosis in preweaning traits of beef cattle. J. Anim. Sci. 24:21.

Henderson, C. R. 1953. Estimation of variance and covariance components. Biometrics 9:226.

Henderson, C. R. 1973. Sire evaluation and genetic trends. Proc. Anim. Breedin $\$$ and Genetics Symp. in honor of Dr. Jay L. Lush. ASAS, ADSA and Poul. Sci. Assoc., Blacksburg, VA.

Henderson, C. R. 1977. Prediction of future records. In: E. Pollak, O. Kempthorne and T. B. Bailey, Jr. (Ed.) Proc. Int. Conf. on Quantitative Genetics. Iowa State Univ. Press, Ames.

Knapp, B. W., O. F. Pahnish, J. J. Urick, J. S. Brinks and G. V. Richardson. 1980. Preweaning and weaning heterosis for maternal effects of beef $X$ beef and beef $X$ dairy crosses. J. Anim. Sci. 50:800.

Koch, R. M., K. E. Gregory and L. V. Cundiff. 1974. Selection in beef cattle. 11. Selection response. J. Anim. Sci. 39:459.

Kramer, C. Y. 1957. Extension of multiple range tests to group correlated adjusted means. Biometrics $13: 13$.

Long, C. R. and K. E. Gregory. 1974. Heterosis and breed effects in preweaning traits of Angus, Hereford and reciprocal cross calves. J. Anim. Sci. 39:11.

Marshall, D. A., W. R. Parker and C. A. Dinkel. 1976. Factors affecting efficiency to weaning in Angus, Charolais and reciprocal cross cows. J. Anim. Sci. $43: 176$.

Notter, D. R., L. V. Cundiff, G. M. Smith, D. B. Laster and K. E. Gregory. 1978. Characterization of biological types of cattle. XII. Milk production in young cows and transmitted and maternal effects on preweaning growth of progeny. J. Anim. Sci. 46:903.

Nwakalor, L. N., J. S. Brinks and G. V. Richardson. 1976. Estimated genetic improvement in weaning weight of beef cattle. J. Anim. Sci. 43:396.

Peacock, F. M., M. Koger and E. M. Hodges. 1978. Weaning traits of Angus, Brahman, Charolais and $F_{1}$ crosses of these breeds. J. Anim. Sci. 47:366.

Preston, J. R. and M. B. Willis. 1974. Intensive Beef Production (2nd Ed.). Pergamon Press, Oxford, England.

Robison, O. W., B. T. McDaniel and E. J. Rincon. 1981. Estimation of direct and maternal additive and heterotic effects from crossbreeding experiments in animals. J. Anim. Sci. $52: 44$.

Rollins, W. C., R. G. Loy, F. D. Carroll and K. A. Wagnon. 1969. Heterotic effects in reproduction and growth to weaning in crosses of the Angus, Hereford and Shorthorn breeds. J. Anim. Sci. 28:431.

Schaeffer, L. R., J. A. Eriksson and J. W. Wilton. 1981. Weighted averages of sire progeny tests for growth traits in Record of Performance beef herds. Can. J. Anim. Sci. 61:35.

Searle, S. R. 1971. Linear Models. John Wiley and Sons, Inc. New York. pp 465-470.

Smith, G. M., D. B. Laster and K. E. Gregory. 1976. Characterization of biological types of cattle. I. Dystocia and preweaning growth. J. Anim. Sci. 43:27.

Wilson, L. L., W. H. Rishel and W. R. Harvey. 1972. Influence of herd, sire and herd $x$ sire interactions on live and carcass characters of beef cattle. J. Anim. Sci. 35:502.

Woldehawariat, G., M. A. Talamantes, R. R. Petty, Jr, and T. C. Cartwright. 1977. A summary of genetic and environmental statistics for growth and conformation characters of young beef cattle (2nd Ed.). Texas Agr. Exp. Sta. Dept. Tech. Rep. No. 103. 